\title{
CRITICAL SOLUTION TEMPERATURES OF MIXTURES OF GASOLINE, ETHYL ALCOHOL, AND WATER
}

\author{
By Oscar C. Bridgeman and Dale Querfeld
}

ABSTRACT

One of the major difficulties encountered with the use of ethyl alcohol-gasoline mixtures as motor fuels arises from the limited solubility of ethyl alcohol in gasoline. Data are presented on the critical solution temperatures of mixtures of eight different gasolines, in proportions from 10 to 90 percent gasoline, with each of eight alcohol solutions containing from 1 to 8 percent of water by volume. It was found that the critical solution temperature decreased markedly as the concentration of water in the alcohol solution decreased and as the percentage of gasoline in the mixture decreased. The critical solution temperatures were found to differ considerably with various gasolines. The present work indicates that addition of other substances to increase the solubility of the alcohol is necessary if gasoline-alcohol mixtures that will not separate in service are to be obtained, unless alcohol almost entirely free from water is employed. The data obtained show that mixtures of gasoline and 95 percent alcohol in equal proportions separate into two phases at temperatures ranging from $14^{\circ}$ to $41^{\circ} \mathrm{C}$., for the eight gasolines studied. If 95 percent alcohol is employed, the alcohol content of the mixture must be not less than about 90 percent, in order that the separation temperature may be below $-20^{\circ} \mathrm{C}$. On the other hand, if 99 percent alcohol is employed, the alcohol content of the mixture can be as low as 10 percent, without separation down to $-20^{\circ} \mathrm{C}$.

\section{CONTENTS}

Page

II. Experimental apparatus and procedure

III. Concentration of alcohol-water solutions employed

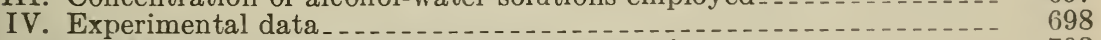

V. Discussion of experimental data and conclusions

\section{INTRODUCTION}

Interest in the possibility of using mixtures of gasoline and ethyl alcohol as motor fuels began almost with the advent of the automobile. This interest has arisen largely from the desire to conserve natural petroleum resources, to provide an outlet for excess production of ethyl alcohol, or to furnish a market for agricultural products by transforming them into ethyl alcohol.

One of the major technical difficulties which has been encountered arises from the limited solubility of ethyl alcohol in gasoline, unless the ethyl alcohol is almost free from water. This is particularly serious in climates in which freezing temperatures occur during the winter. Furthermore, provision must be made for the possibility of absorption of moisture during use, which makes it essential to introduce a suitable factor of safety as a precautionary measure. Due to the low solubility of commercial (95 percent) ethyl alcohol in gasolines, particularly at low temperatures, it is necessary either to use alcohol 
almost free from water or to add other substances to increase the solubility. Preparatory to an investigation of such substances, it

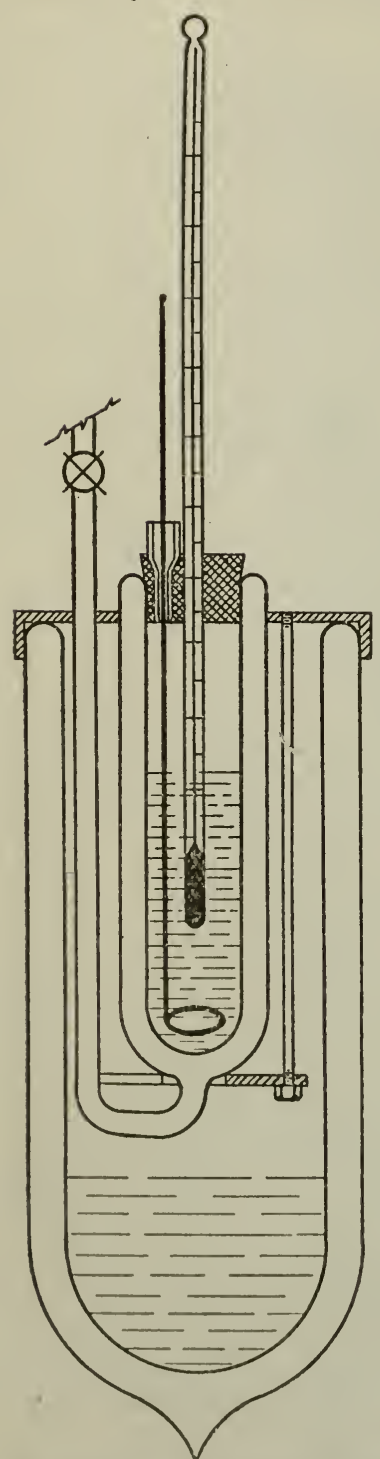

Figure 1.-Apparatus used for the measurement of the critical solution temperatures of gasoline-alcohol mixlures.

seemed desirable to obtain a comprehensive set of data on the solubility in a number of gasolines of ethyl alcohol containing various percentages of water. The present paper covers the information obtained in this preliminary investigation, using eight. different gasolines, and includes data obtained on the temperatures below which ethyl alcohol containing up to 8 percent of water is not completely miscible with each of these gasolines when blended in various proportions from 10 to 90 percent of gasoline.

There appears to be little published information on the subject. A number of investigators ${ }^{1}$ have used the solubility in kerosene as a criterion of the water content of ethyl alcohol and have given some data on critical solution temperatures for alcohol containing various percentages of water. A limited set of data on the solubility of aqueous ethyl alcohol solutions in six gasolines has been given by Ormandy and Craven. $^{2}$ Hubendick ${ }^{3}$ also gives a few values for the solubility of alcohol in motor gasoline. Nicolardot ${ }^{4}$ has done considerable work on the solubility problem when aromatic hydrocarbons or other materials are added, but did little work on simple blends of ethyl alcohol and gasoline. Data on one aviation gasoline have also been reported by Sparrow. ${ }^{5}$

\section{EXPERIMENTAL APPARATUS AND PROCEDURE}

The general procedure used in the present work consisted in preparing quantitatively solutions of ethyl alcohol, of known water content, and gasoline, and in measuring the critical solution temperatures by noting the appearance of a second phase on cooling.

A diagram of the apparatus used for measuring the critical solution temperatures is shown in figure 1. The tube used for holding the alcohol-gasoline blend during the determination was similar to a Dewar cylinder except that a glass tube was connected to the bottom so as to permit varying the air pressure in the annular space in order

1 For a complete discussion of work along these lines together with references, see McKelvy, B.S.Bull. vol. 9, p. 344,1913

2. Ormandy and Craven, Proc. Inst. Auto. Eng., vol. 18 (1), p. 313, 1924.

3 Hubendick, Trans. Fuel Conference. World Power Conference, vol. 3, p. 724, 1928.

- Nicolardot, La Technique Automobile, No. 115, fourth Trimestre, 1921.

- Sparrow, N.A.C.A. Technical Report, No. 232, 1925. 
to control the rate of heat transfer across this space. The inside tube of the double-walled container was $20 \mathrm{~mm}$ in diameter and $150 \mathrm{~mm}$ long, and the width of the annular space was $2 \mathrm{~mm}$. A cork stopper was used to close tightly the mouth of the tube and provision was made for inserting a thermometer and a stirrer. The thermometer was supported by making it fit tightly in the cork stopper. The stirrer was made of $1 / 8$-inch brass rod, bent into a loop at the bottom. A packing gland was employed where the stirrer rod passed through the cork stopper. This gland consisted simply of a brass tube, of design shown in figure 1 , which fitted tightly into a hole in the cork stopper, and the space between the brass tube and the rod passing through it was filled with absorbent cotton. A packing gland was found to be necessary to prevent absorption of moisture by the alcohol-gasoline mixture. A special brass holder, shown in figure 1, was constructed for holding the double-walled container. A Dewar cylinder was provided for holding the liquid used to cool the alcohol-gasoline mixture.

A mercury-in-glass thermometer graduated in $0.2^{\circ} \mathrm{C}$. was used for temperature measurements down to $-36^{\circ} \mathrm{C}$., while for temperatures below this, a toluene thermometer similarly graduated was employed. Both thermometers were calibrated as partial immersion instruments.

Immediately before each determination, the particular alcoholgasoline mixture under investigation was prepared. By means of calibrated pipettes, appropriate amounts of the alcohol and gasoline were introduced into a small ground-stoppered flask, where they were thoroughly mixed and warmed if necessary in order to effect solution. No special precautions were taken to prepare the mixtures at any definite temperature, since the coefficients of expansion of the gasolines and the aqueous alcohol solutions were so nearly alike, being on the average 0.00115 for the former and 0.00108 for the latter. If the gasoline and the alcohol solution were at the same temperature when mixed, then a variation in mixing temperature of $20^{\circ} \mathrm{C}$., which was a maximum for the present work, would introduce an error in the amount of each constituent in the mixture of less than 2 parts in 1,000 , when referred to $60^{\circ} \mathrm{F}$. as the standard temperature. Precautions were taken, however, to insure that the gasoline and the ethyl alcohol solution were very close to the same temperature before mixing, by storing their respective containers in close proximity to one another. A temperature difference of $2^{\circ} \mathrm{C}$. would introduce an error in the amount of each constituent in the mixture of only 2 parts in 1,000. While greater precision could have been obtained by preparing the mixtures at a definite temperature, the general accuracy desired did not appear to warrant the more elaborate procedure necessary for high precision.

About $15 \mathrm{ml}$ of the mixture was transferred to the double-walled container, which was then closed with the stopper holding the thermometer and stirrer. In order to prevent separation of the alcoholgasoline mixture into two phases during this transfer, the doublewalled container was warmed if necessary. In the above procedure of preparing the mixtures and transferring them to the apparatus preparatory to making a measurement, the pipettes, the flask, the double-walled container, the thermometer, and the stirrer were all carefully cleaned and dried in advance.

After the introduction of the sample, the tube was placed in the brass holder and was inserted into the Dewar cylinder containing either liquid air or cold water, depending upon the anticipated critical 
solution temperature. The rate of cooling was maintained at $1^{\circ}$ to $2^{\circ} \mathrm{C}$. per minute, either by controlling the pressure in the air space between the double walls of the container, or by regulating the depth of immersion in the cooling medium, or by adjusting the height of cooling liquid in the Dewar cylinder. All three methods were employed, although a combination of the last two was found to be the most convenient. In general, the temperature of the sample was adjusted to a value about $5^{\circ}$ to $10^{\circ} \mathrm{C}$. above the anticipated critical solution temperature before each determination. As the temperature dropped, the mixture was stirred vigorously until at some definite temperature for each mixture, a turbidity suddenly appeared, indicating the separation of a second phase. This temperature was recorded as the critical solution temperature, being the lowest temperature at which the alcohol solution and gasoline under investigation are completely miscible in the given proportions employed. A check deter-

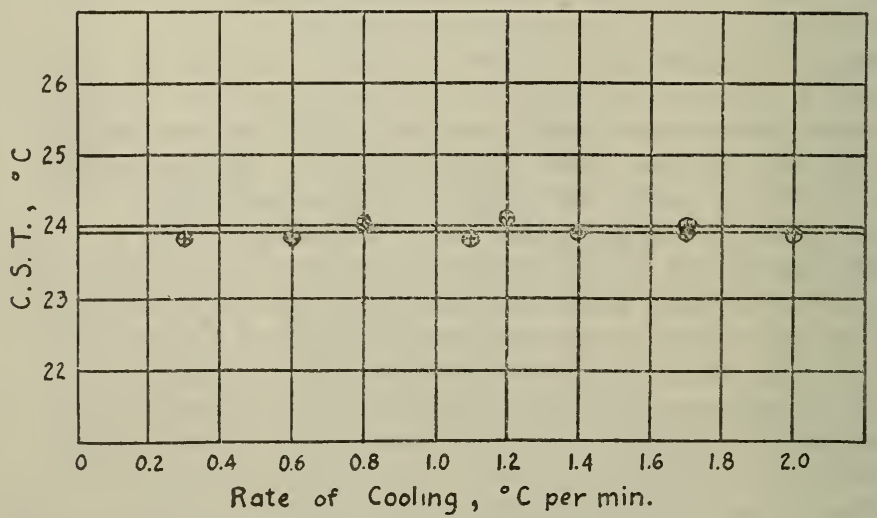

FIGURE 2.-Data on the critical solution temperature (C.S.T.) of a representative mixture measured at different rates of cooling

mination was made on each mixture without removing the sample in order to determine whether there was any significant rate of absorption of moisture during the measurement. Duplicate values agreed very well, the average difference being less than $0.2^{\circ} \mathrm{C}$. In a number of cases, the temperatures were read at which the turbidity disappeared on heating. These values checked the temperatures at which turbidity appeared on cooling, within $0.2^{\circ} \mathrm{C}$. on the average, thus assuring that the critical solution temperatures measured were very close to the equilibrium values.

The rate of cooling employed, namely, $1^{\circ}$ to $2^{\circ} \mathrm{C}$. per minute, was chosen on the basis of preliminary experiments made to establish a rate of cooling which would expedite the measurements and still permit the attainment of the desired accuracy. A representative set of data are shown in figure 2. It is seen that there is no trend in the values of the measured critical solution temperature over the range of rates of cooling investigated. 


\section{CONCENTRATION OF ALCOHOL-WATER SOLUTIONS EMPLOYED}

Eight ethyl alcohol solutions were used containing volume percentages of alcohol ranging from about 93 to 99 percent. These solutions were prepared from pure, absolute ethyl alcohol by additiori of appropriate amounts of distilled water, and shaking thoroughly. The composition of the alcohol-water solutions was determined from measurements of their density. The pycnometers used had approximate volumes of $21 \mathrm{ml}$ and were of the type described by Osborne. ${ }^{6}$ They were carefully calibrated with distilled water at $30.00^{\circ} \mathrm{C}$. which was the temperature used in all density measurements. Check determinations were made on all alcohol solutions, the precision in measurement being 1 part in 5,000.

The alcohol solutions were made up in batches of 1 liter at a time and were stored in flasks with ground stoppers. New solutions of approximately the same concentrations were prepared when needed. The concentration of each alcohol solution was checked periodically, and the solution was discarded if the volume percent of alcohol changed by more than 1 part in 2,000. In most cases, the solution was used up before a change of this magnitude was observed.

The average compositions of the various ethyl alcohol solutions employed are given in table 1, where letters are used to designate solutions differing in concentration by about 0.8 volume percent of alcohol, while numbers are used to designate successive batches of solutions of the same approximate composition. Values of the $60^{\circ} / 60^{\circ}$ specific gravity, and of the $60^{\circ} \mathrm{F}$. volume percentages of ethyl alcohol and of water are given. Volume percent is the volume of pure ethyl alcohol, or of pure water, respectively, at $60^{\circ} \mathrm{F}$. in $100 \mathrm{ml}$ of solution at $60^{\circ} \mathrm{F}$. Since there is a contraction in volume on mixing ethyl alcohol and water, the sum of the volume percentages of these two constituents exceeds 100 .

TABLE 1.-Concentrations of ethyl-alcohol solutions

\begin{tabular}{|c|c|c|c|}
\hline No. & $\begin{array}{l}60^{\circ} / 60^{\circ} \\
\text { specific } \\
\text { gravity }\end{array}$ & $\begin{array}{l}\text { Volume } \\
\text { percent } \\
\text { alcohol } \\
\text { at } 60^{\circ} \mathrm{F} \text {. }\end{array}$ & $\begin{array}{c}\text { Volume } \\
\text { percent } \\
\text { water at } \\
60^{\circ} \mathrm{F} \text {. }\end{array}$ \\
\hline $\mathrm{A}$ & $\begin{array}{r}0.79820 \\
.79826\end{array}$ & $\begin{array}{l}99.144 \\
99.131\end{array}$ & $\begin{array}{l}1.110 \\
1.127\end{array}$ \\
\hline $\begin{array}{l}\text { B } \\
\text { B1- } \\
\text { B2 }\end{array}$ & $\begin{array}{l}.80202 \\
.80207 \\
.80199\end{array}$ & $\begin{array}{l}\text { 98. } 337 \\
98.325 \\
98.344\end{array}$ & $\begin{array}{l}\text { 2. } 133 \\
\text { 2. } 149 \\
\text { 2. } 124\end{array}$ \\
\hline $\begin{array}{l}\text { C } 1 \ldots \\
\text { C1-..... } \\
\text { C2 } 2\end{array}$ & $\begin{array}{l}.80565 \\
.80580 \\
.80586\end{array}$ & $\begin{array}{l}97.528 \\
97.492 \\
97.479\end{array}$ & $\begin{array}{l}\text { 3. } 139 \\
\text { 3. } 182 \\
3.199\end{array}$ \\
\hline $\begin{array}{l}\text { D } \\
\text { D1............. } \\
\text { D2 }\end{array}$ & $\begin{array}{l}.80917 \\
.80927 \\
.80930\end{array}$ & $\begin{array}{l}\text { 96. } 703 \\
96.679 \\
96.672\end{array}$ & $\begin{array}{l}\text { 4. } 145 \\
\text { 4. } 175 \\
\text { 4. } 184\end{array}$ \\
\hline $\begin{array}{l}\mathrm{E} \\
\mathrm{E} 1 \ldots \\
\mathrm{E} 2 \ldots\end{array}$ & $\begin{array}{l}.81269 \\
.81274 \\
.81257\end{array}$ & $\begin{array}{l}95.845 \\
95.833 \\
95.875\end{array}$ & $\begin{array}{l}5.178 \\
\text { 5. } 193 \\
5.143\end{array}$ \\
\hline $\begin{array}{l}\text { F } \\
\text { F } 11\end{array}$ & $\begin{array}{l}.81608 \\
.81609 \\
.81615\end{array}$ & $\begin{array}{l}\text { 94. } 987 \\
94.984 \\
94.970\end{array}$ & $\begin{array}{l}\text { 6. } 196 \\
\text { 6. } 201 \\
\text { 6. } 218\end{array}$ \\
\hline 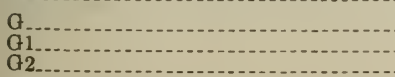 & $\begin{array}{l}.81948 \\
.81940 \\
.81961\end{array}$ & $\begin{array}{l}94.097 \\
94.119 \\
94.061\end{array}$ & $\begin{array}{l}7.243 \\
\text { 7. } 217 \\
\text { 7. } 285\end{array}$ \\
\hline $\begin{array}{l}\mathrm{H} \\
\mathrm{H} \\
\mathrm{H} 1\end{array}$ & $\begin{array}{l}.82264 \\
.82281 \\
.82275\end{array}$ & $\begin{array}{l}\text { 93. } 243 \\
93.196 \\
93.210\end{array}$ & $\begin{array}{l}\text { 8. } 237 \\
\text { 8. } 291 \\
\text { 8. } 275\end{array}$ \\
\hline
\end{tabular}

- Osborne, B.S.Bull, vol. 9, p. 405, 1913. 


\section{EXPERIMENTAL DATA}

Data were obtained on eight motor gasolines which are described in table 2. The first six fuels were straight-r'un products, obtained from a number of different crude oils. The last two fuels were 100 percent cracked products, obtained by two different cracking processes.

With each gasoline, mixtures containing from 10 to 90 percent gasoline by even steps of 10 percent were prepared with the alcohol solution of each concentration, and measurements of the critical solution temperature were made. There was no attempt to measure critical solution temperatures lying outside of the approximate range from $+65^{\circ}$ to $-65^{\circ} \mathrm{C}$. No account was taken of any change in volume on mixing the gasoline with the alcohol solution. Accordingly, the volume percent of gasoline in the mixture, referred to throughout this paper is the volume of gasoline at $60^{\circ} \mathrm{F}$. which, when mixed with the appropriate volume of alcohol solution, gives a summation of volumes equal to 100 at $60^{\circ} \mathrm{F}$. It is considered that the volume percents of gasoline were accurate to better than 0.5 units.

TABLE 2.-Identification data on gasolines

\begin{tabular}{|c|c|c|c|c|c|}
\hline \multirow{2}{*}{ No. } & \multirow{2}{*}{ Source } & \multicolumn{3}{|c|}{$\begin{array}{l}\text { Temperature at stated per- } \\
\text { centages evaporated }\end{array}$} & \multirow{2}{*}{$\begin{array}{l}60^{\circ} / 60^{\circ} \\
\text { specific } \\
\text { gravity }\end{array}$} \\
\hline & & 10 percent & 50 percent & t 90 percent & \\
\hline $\begin{array}{l}1 \\
2 \\
3 \\
4\end{array}$ & $\begin{array}{l}\text { Pennsylvania } \\
\text { Rumania } \\
\text { California } \\
\text { Oklahoma. }\end{array}$ & $\begin{array}{r}{ }^{\circ} C . \\
76 \\
70 \\
66 \\
72\end{array}$ & $\begin{array}{l}{ }^{\circ} C_{135} \\
135 \\
106 \\
108 \\
124\end{array}$ & $\begin{array}{r}{ }^{\circ} \mathrm{C} \\
199 \\
152 \\
154 \\
194\end{array}$ & $\begin{array}{r}0.738 \\
.734 \\
.730 \\
.740\end{array}$ \\
\hline $\begin{array}{l}5 \\
6 \\
7 \\
8\end{array}$ & $\begin{array}{l}\text { California } \\
\text { East Texas } \\
100 \text { percent cracked. }\end{array}$ & $\begin{array}{l}58 \\
58 \\
54 \\
69\end{array}$ & $\begin{array}{l}110 \\
110 \\
126 \\
142\end{array}$ & $\begin{array}{l}156 \\
162 \\
188 \\
194\end{array}$ & $\begin{array}{l}.732 \\
.723 \\
.754 \\
.773\end{array}$ \\
\hline
\end{tabular}

The data obtained on the eight gasolines are given in tables 3 to 10, inclusive. The critical solution temperatures recorded are the means of two determinations on each mixture. It is seen that the critical solution temperature decreases markedly as the concentration of the water in the alcohol solution decreases and as the percentage of gasoline in the mixture decreases.

The values for gasolines nos. 1 and 7 are shown graphically in figures 3 and 4 , where the different curves correspond to the data on the blends with the various alcohol solutions. These two gasolines were chosen for illustration, since the critical solution temperatures for the former are the highest obtained for the gasolines investigated, while the critical solution temperatures for the latter are the lowest values obtained. The data on these two gasolines are plotted in a different manner in figures 5 and 6 to show the critical solution temperatures for various percentages of water in the mixtures. In this case the different curves correspond to various percentages of gasoline in the mixtures. 


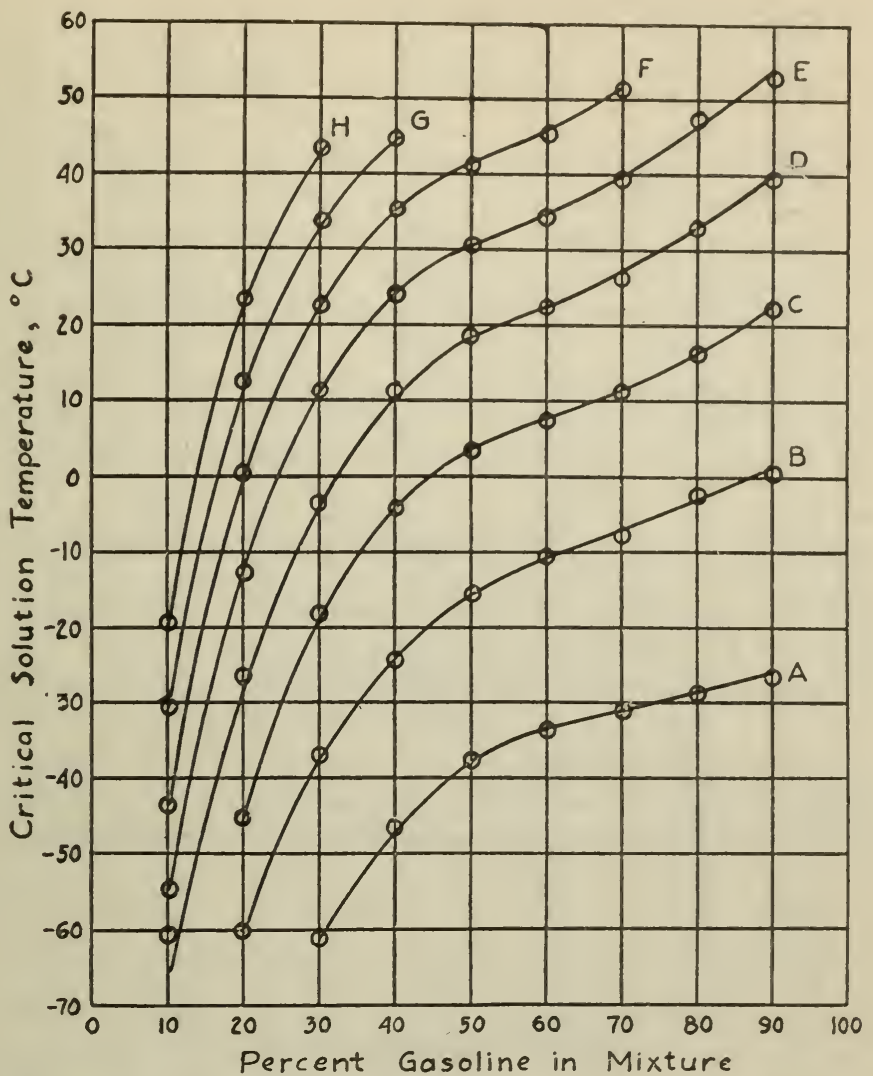

FIGURE 3.-Data on the critical solution temperatures of mixtures of ethyl alcohol and gasoline no. 1 in various proportions.

Each curve represents values on mixtures with ethyl alcohol of a definite alcohol concentration symbolized by a letter and recorded in table 1.

TABLE 3.-Critical solution temperatures of mixtures with gasoline no. 1

\begin{tabular}{|c|c|c|c|c|c|c|c|c|c|}
\hline \multirow{2}{*}{ Alcohol solution } & \multicolumn{9}{|c|}{ Volume percent gasoline in mixture } \\
\hline & 10 & 20 & 30 & 40 & 50 & 60 & 70 & 80 & 90 \\
\hline & $\begin{array}{c}{ }^{\circ} \mathrm{C} . \\
-60.6\end{array}$ & $\begin{array}{l}{ }^{\circ} \mathrm{C} . \\
-60.0 \\
-45.0 \\
-26.2\end{array}$ & $\begin{array}{r}{ }^{\circ} C . \\
-61.0 \\
-36.8 \\
-18.0 \\
-3.2\end{array}$ & $\begin{array}{r}{ }^{\circ} \mathrm{C} . \\
-46.2 \\
-24.0 \\
-4.1 \\
11.5\end{array}$ & $\begin{array}{r}{ }^{\circ} C . \\
-37.4 \\
-15.1 \\
3.7 \\
18.7\end{array}$ & $\begin{array}{r}{ }^{\circ} \mathrm{C} . \\
-33.4 \\
-10.3 \\
7.7 \\
22.4\end{array}$ & $\begin{array}{r}{ }^{\circ} C . \\
-31.0 \\
-7.4 \\
11.3 \\
26.6\end{array}$ & $\begin{array}{r}{ }^{\circ} C . \\
-28.3 \\
-2.5 \\
16.6 \\
33.1\end{array}$ & $\begin{array}{r}{ }^{\circ} \mathrm{C} . \\
-26.4 \\
.8 \\
22.3 \\
39.4\end{array}$ \\
\hline & $\begin{array}{l}-54.7 \\
-43.2 \\
-30.2 \\
-19.3\end{array}$ & $\begin{array}{r}-12.7 \\
.3 \\
12.6 \\
23.2\end{array}$ & $\begin{array}{l}11.3 \\
22.5 \\
33.7 \\
43.2\end{array}$ & $\begin{array}{l}24.3 \\
35.3 \\
45.0\end{array}$ & $\begin{array}{r}30.8 \\
41.6 \\
\end{array}$ & $\begin{array}{l}34.4 \\
45.7\end{array}$ & $\begin{array}{l}39.5 \\
51.6\end{array}$ & 47.7 & 52.8 \\
\hline
\end{tabular}




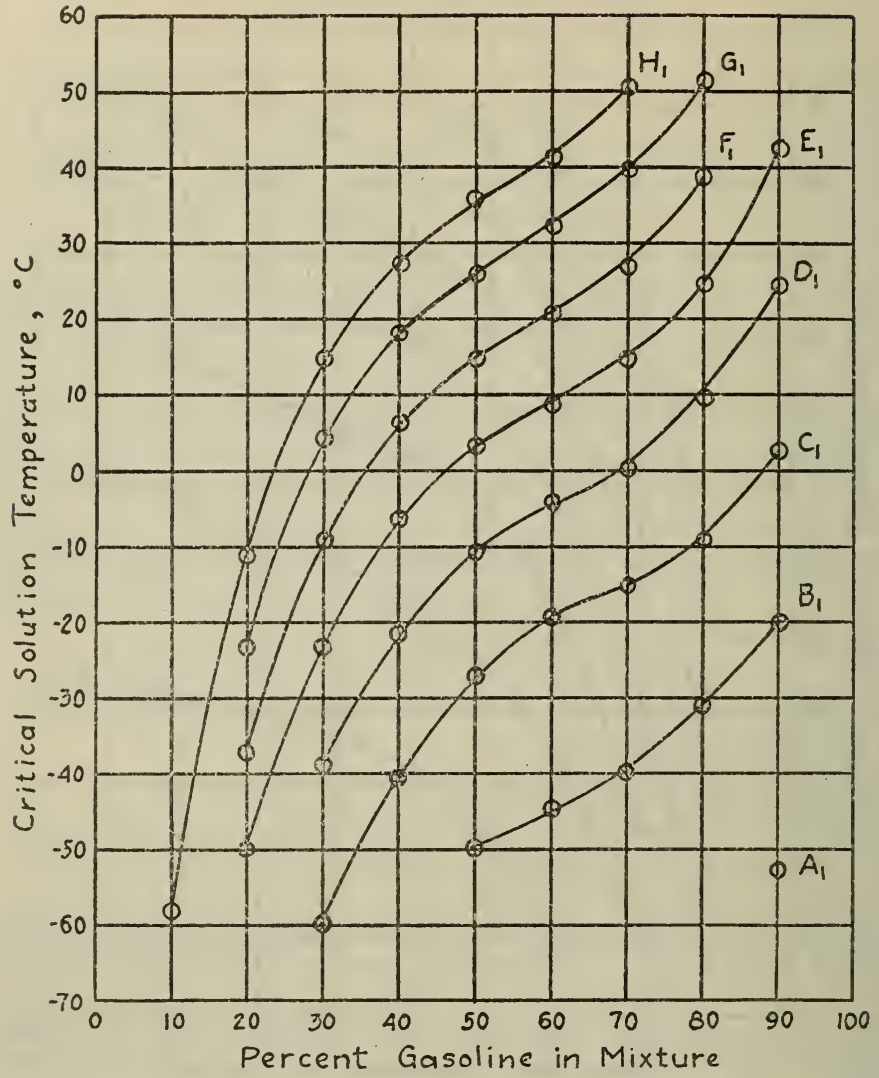

FIgURE 4.-Data on the critical solution temperatures of mixtures of ethyl alcohol and gasoline no. 7 in various proportions.

Each curve represents values on mixtures with ethyl alcohol of a definite alcohol concentration symbolized by a letter and recorded in table 1 .

TABLE 4.-Critical solution temperatures of mixtures with gasoline no. 2

\begin{tabular}{|c|c|c|c|c|c|c|c|c|c|}
\hline \multirow{2}{*}{ Alcohol solution } & \multicolumn{9}{|c|}{ Volume percent gasoline in mixture } \\
\hline & 10 & 20 & 30 & 40 & 50 & 60 & 70 & 80 & 90 \\
\hline & ${ }^{\circ} \mathrm{C}$ & $\begin{array}{c}{ }^{\circ} \mathrm{C} . \\
-59.9\end{array}$ & $\begin{array}{l}{ }^{\circ} \mathrm{C} . \\
-53.5 \\
-35.4\end{array}$ & $\begin{array}{l}{ }^{\circ} \mathrm{C} . \\
-56.5 \\
-34.5 \\
-16.5\end{array}$ & $\begin{array}{r}{ }^{\circ} C . \\
-67.0 \\
-43.6 \\
-21.5 \\
-5.4\end{array}$ & $\begin{array}{r}{ }^{\circ} C . \\
-60.7 \\
-35.3 \\
-15.0 \\
-0.2\end{array}$ & $\begin{array}{r}{ }^{\circ} \mathrm{C} . \\
-55.6 \\
-30.4 \\
-10.8 \\
5.8\end{array}$ & $\begin{array}{r}{ }^{\circ} \mathrm{C} . \\
-52.3 \\
-24.2 \\
-3.0 \\
14.5\end{array}$ & $\begin{array}{r}{ }^{\circ} C . \\
-47.9 \\
-16.2 \\
7.6 \\
27.0\end{array}$ \\
\hline & -57.0 & $\begin{array}{r}-47.9 \\
-33.2 \\
-20.4 \\
-7.8\end{array}$ & $\begin{array}{r}-18.5 \\
-1.5 \\
7.3 \\
17.7\end{array}$ & $\begin{array}{r}-1.3 \\
11.1 \\
22.2 \\
32.2\end{array}$ & $\begin{array}{r}8.5 \\
20.1 \\
30.7 \\
40.7\end{array}$ & $\begin{array}{l}14.0 \\
25.6 \\
36.5 \\
46.4\end{array}$ & $\begin{array}{l}19.7 \\
32.4 \\
44.4\end{array}$ & $\begin{array}{c}29.4 \\
44.4 \\
\end{array}$ & $\begin{array}{r}41.9 \\
\end{array}$ \\
\hline
\end{tabular}




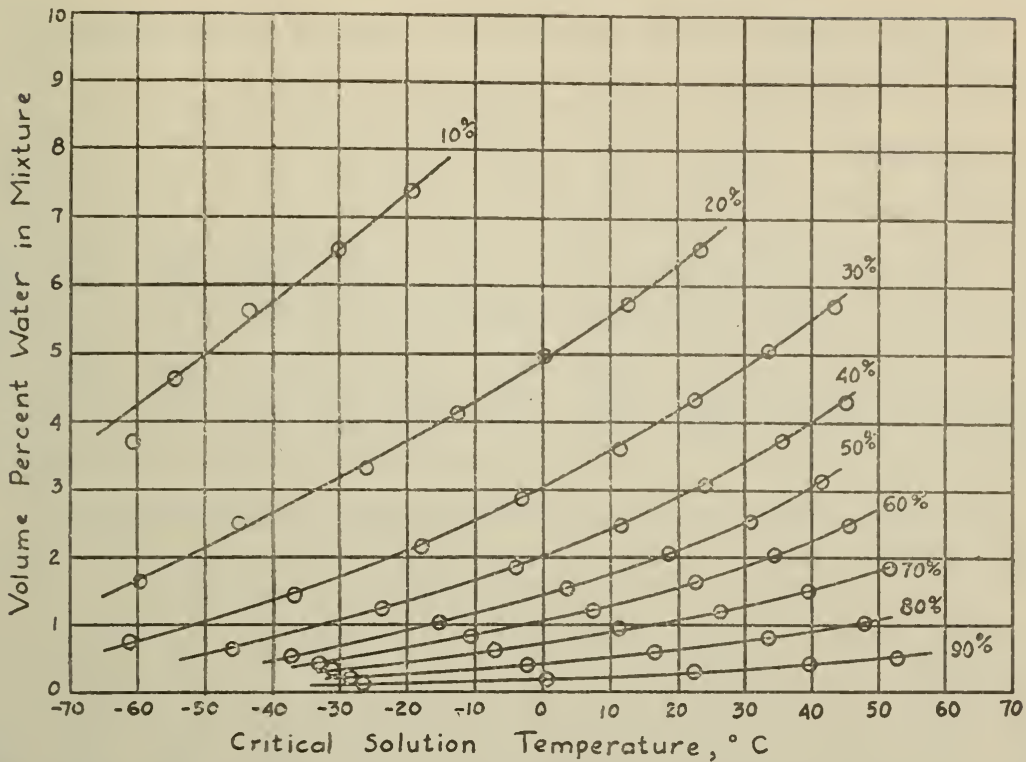

FIGURE 5.-Data on the critical solution temperatures of mixtures of ethyl alcohol and gasoline no. 1 for various volume percentages of water in the mixtures.

The different curves represent different constant percentages of gasoline in the mixtures.

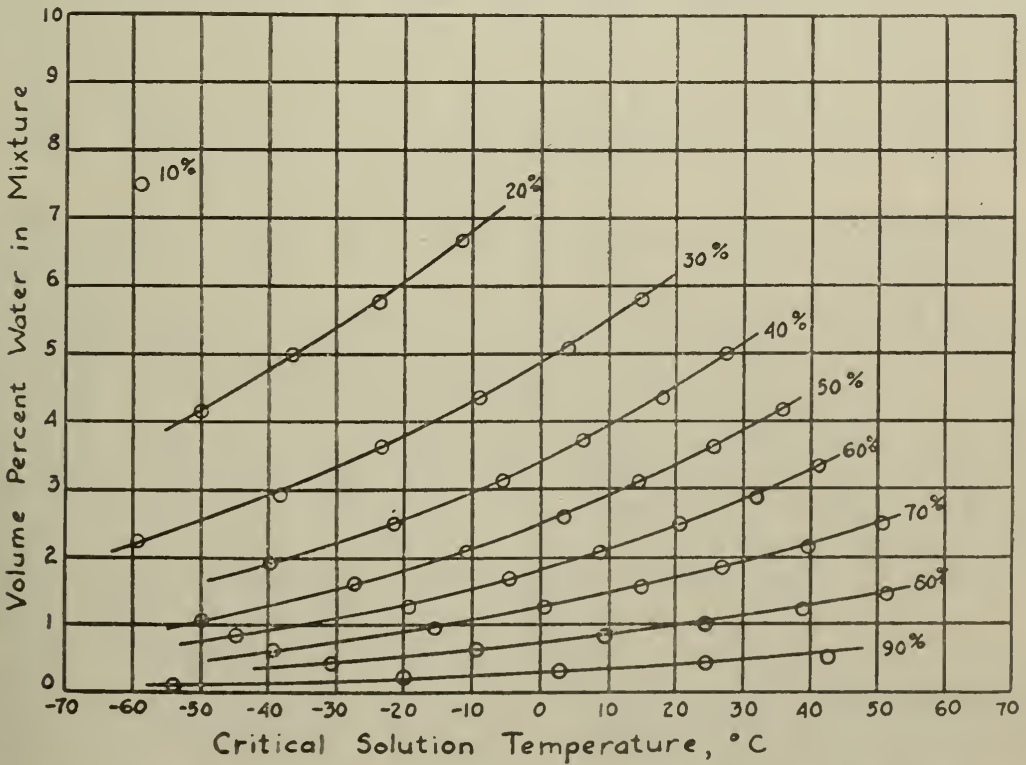

FIGURE 6.-Data on the critical solution temperatures of mixtures of ethyl alcohol and gasoline no. 7 for various volume percentages of water in the mixtures.

The different curves represent different constant percentages of gasoline in the mixtures.

$167156-33 \longrightarrow 9$ 
TABLE 5.-Critical solution temperatures of mixtures with gasoline no. 8

\begin{tabular}{|c|c|c|c|c|c|c|c|c|c|}
\hline \multirow{2}{*}{ Alcohol solution } & \multicolumn{9}{|c|}{ Volume percent gasoline in mixture- } \\
\hline & 10 & 20 & 30 & 40 & 50 & 60 & 70 & 80 & 90 \\
\hline & ${ }^{\circ} \mathrm{C}$. & ${ }^{\circ} \mathrm{C}$. & ${ }^{\circ} \mathrm{C}$. & ${ }^{\circ} \mathrm{C}$. & $\begin{array}{c}{ }^{\circ} \mathrm{C} . \\
-64.8\end{array}$ & $\begin{array}{l}{ }^{\circ} \mathrm{C} . \\
-57.7\end{array}$ & $\begin{array}{c}{ }^{\circ} C . \\
-54.5\end{array}$ & $\begin{array}{c}{ }^{\circ} \mathrm{C} \\
-50.0\end{array}$ & ${ }_{-44.3}^{\circ} \mathrm{C}$. \\
\hline B. & & & -46.3 & $\begin{array}{l}-52.3 \\
-31.2\end{array}$ & $\begin{array}{l}-40.6 \\
-19.7\end{array}$ & $\begin{array}{l}-33.8 \\
-12.8\end{array}$ & $\begin{array}{l}-28.2 \\
-7.2\end{array}$ & -21.4 & -12.5 \\
\hline D.. & & -60.4 & $\begin{array}{l}-40.3 \\
-28.3\end{array}$ & -13.0 & -3.0 & $\begin{array}{r}-12.8 \\
3.4\end{array}$ & $\begin{array}{r}-1.2 \\
9.3\end{array}$ & $\begin{array}{c}-0.2 \\
17.1\end{array}$ & 29.7 \\
\hline E. & & -45.3 & -11.6 & 1.6 & 10.9 & 16.8 & 22.6 & 32.2 & 43.6 \\
\hline G. & -65.0 & $\begin{array}{l}-31.8 \\
-17.4\end{array}$ & $\begin{array}{r}-2.8 \\
11.3\end{array}$ & $\begin{array}{l}13.4 \\
24.7\end{array}$ & $\begin{array}{l}2.5 \\
33.5\end{array}$ & $\begin{array}{l}28.0 \\
39.1\end{array}$ & $\begin{array}{l}35.3 \\
47.0\end{array}$ & 46.7 & \\
\hline & -54.9 & -6.2 & 21.1 & 35.0 & 44.0 & 49.3 & & & \\
\hline
\end{tabular}

TABLE 6.-Critical solution temperatures of mixtures with gasoline no. 4

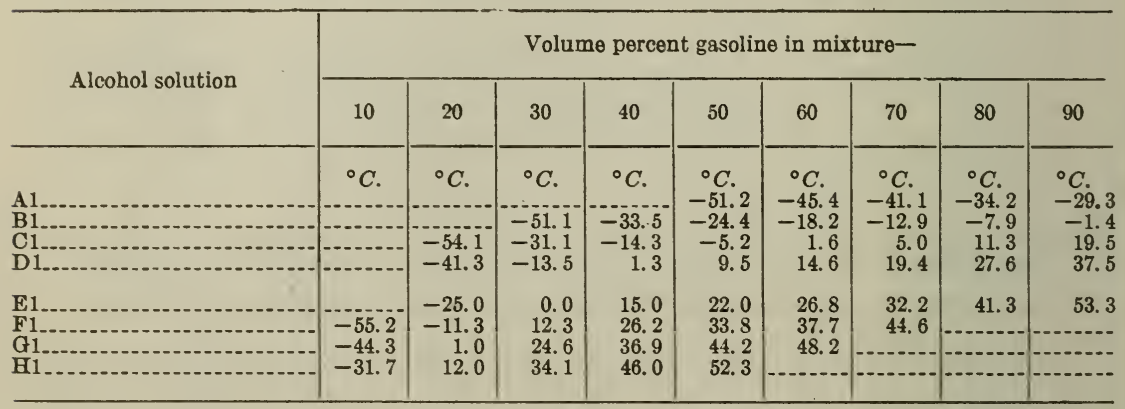

TABLE 7.-Critical solution temperatures of mixtures with gasoline no. 5

\begin{tabular}{|c|c|c|c|c|c|c|c|c|c|}
\hline \multirow{2}{*}{ Alcohol solution } & \multicolumn{9}{|c|}{ Volume percent gasoline in mixture- } \\
\hline & 10 & 20 & 30 & 40 & 50 & 60 & 70 & 80 & 90 \\
\hline & ${ }^{\circ} \mathrm{C}$. & ${ }^{\circ} \mathrm{C}$. & ${ }^{\circ} \mathrm{C}$. & ${ }^{\circ} \mathrm{C}$. & ${ }^{\circ} \mathrm{C}$. & ${ }^{\circ} \mathrm{C}$. & ${ }^{\circ} \mathrm{C}$. & ${ }^{\circ} \mathrm{C}$. & ${ }_{-43}^{\circ} \mathrm{C}$ \\
\hline $\begin{array}{l}\text { B1- } \\
\text { C1. } \\
\text { D1. }\end{array}$ & & & $\begin{array}{l}-52.1 \\
-35.6\end{array}$ & $\begin{array}{l}-34.4 \\
-15.8\end{array}$ & $\begin{array}{r}-42.5 \\
-20.4 \\
-4.1\end{array}$ & $\begin{array}{r}-34.0 \\
-14.2 \\
2.8\end{array}$ & $\begin{array}{r}-28.5 \\
-8.5 \\
8.4\end{array}$ & $\begin{array}{r}-22.0 \\
-17.7\end{array}$ & $\begin{array}{r}-11.8 \\
12.5 \\
31.1\end{array}$ \\
\hline $\begin{array}{l}\text { E1.- } \\
\text { F1:- } \\
\text { G1:- }\end{array}$ & & $\begin{array}{l}-49.1 \\
-33.7 \\
-20.3\end{array}$ & $\begin{array}{r}-18.8 \\
-5.0 \\
7.4\end{array}$ & $\begin{array}{r}-0.9 \\
12.1 \\
23.2\end{array}$ & $\begin{array}{r}9.7 \\
20.5 \\
32.1\end{array}$ & $\begin{array}{l}15.5 \\
27.4 \\
37.9\end{array}$ & $\begin{array}{l}22.2 \\
34.6 \\
46.1\end{array}$ & $\begin{array}{l}32.4 \\
46.4\end{array}$ & 46.2 \\
\hline H1.. & & -8.5 & 18.4 & 33.1 & 41.7 & 47.7 & & & \\
\hline
\end{tabular}

TABLE 8.-Critical solution temperatures of mixtures with gasoline no. 6

\begin{tabular}{|c|c|c|c|c|c|c|c|c|c|}
\hline \multirow{2}{*}{ Alcohol solution } & \multicolumn{9}{|c|}{ Volume percent gasoline in mixture- } \\
\hline & 10 & 20 & 30 & 40 & 50 & 60 & 70 & 80 & 90 \\
\hline & ${ }^{\circ} \mathrm{C}$. & ${ }^{\circ} \mathrm{C}$. & ${ }^{\circ} \mathrm{C}$. & ${ }^{\circ} \mathrm{C}$. & ${ }^{\circ} \mathrm{C}$ & ${ }^{\circ} \mathrm{C}$ & ${ }^{\circ} \mathrm{C}$. & $\begin{array}{l}{ }^{\circ} \mathrm{C} . \\
-46.0\end{array}$ & $\begin{array}{l}{ }^{\circ} \mathrm{C} . \\
-39.8\end{array}$ \\
\hline $\begin{array}{l}\text { B2.- } \\
\text { C2 } \\
\text { D2.-. }\end{array}$ & & -59.2 & $\begin{array}{l}-47.9 \\
-29.3\end{array}$ & $\begin{array}{l}-48.3 \\
-28.2 \\
-11.4\end{array}$ & $\begin{array}{r}-37.9 \\
-16.6 \\
-.4\end{array}$ & $\begin{array}{r}-29.4 \\
-9.6 \\
5.7\end{array}$ & $\begin{array}{r}-25.1 \\
-4.5 \\
10.8\end{array}$ & $\begin{array}{r}-46.0 \\
-19.5 \\
2.2 \\
19.7\end{array}$ & $\begin{array}{r}-39.8 \\
-10.2 \\
13.7 \\
33.0\end{array}$ \\
\hline $\begin{array}{l}\mathrm{E} 2 \\
\mathrm{~F} 2 \\
\mathrm{G} 2\end{array}$ & & $\begin{array}{l}-43.0 \\
-26.5 \\
-14.4\end{array}$ & $\begin{array}{r}-13.9 \\
0.0 \\
12.5\end{array}$ & $\begin{array}{r}3.2 \\
15.7 \\
26.8\end{array}$ & $\begin{array}{l}13.4 \\
24.2 \\
36.0\end{array}$ & $\begin{array}{l}18.7 \\
30.0 \\
41.0\end{array}$ & $\begin{array}{l}24.7 \\
37.1 \\
49.3\end{array}$ & $\begin{array}{l}35.0 \\
49.7\end{array}$ & 46.0 \\
\hline & -50.9 & -2.1 & 23.0 & 36.6 & 44.4 & & & & \\
\hline
\end{tabular}


TABLE 9.-Critical soluiion temperatures of mixtures with gasoline no. $\boldsymbol{\gamma}$

\begin{tabular}{|c|c|c|c|c|c|c|c|c|c|}
\hline \multirow{2}{*}{ Alcohol solution } & \multicolumn{9}{|c|}{ Volume percent gasoline in mixture- } \\
\hline & 10 & 20 & 30 & 40 & 50 & 60 & 70 & 80 & 90 \\
\hline A1. & ${ }^{\circ} \mathrm{C}$. & ${ }^{\circ} \mathrm{C}$. & ${ }^{\circ} \mathrm{C}$. & ${ }^{\circ} \mathrm{C}$. & ${ }^{\circ} \mathrm{C}$. & ${ }^{\circ} \mathrm{C}$. & ${ }^{\circ} \mathrm{C}$. & ${ }^{\circ} \mathrm{C}$. & ${ }_{-53.1}^{\circ}$ \\
\hline $\begin{array}{l}\text { B1... } \\
\text { C1... } \\
\text { D1.. }\end{array}$ & 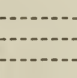 & - & $\begin{array}{r}-59.9 \\
-38.8\end{array}$ & $\begin{array}{r}-40.0 \\
-21.6\end{array}$ & $\begin{array}{l}-49.8 \\
-26.8 \\
-10.9\end{array}$ & $\begin{array}{r}-44.8 \\
-19.3 \\
-4.6\end{array}$ & $\begin{array}{r}-40.1 \\
-15.9 \\
.7\end{array}$ & $\begin{array}{r}-30.9 \\
-9.3 \\
9.6\end{array}$ & $\begin{array}{r}-19.9 \\
2.8 \\
24.5\end{array}$ \\
\hline $\begin{array}{l}\text { E1-. } \\
\text { F1- } \\
\text { Q1-- }\end{array}$ & - & $\begin{array}{l}-50.2 \\
-37.0 \\
-23.6\end{array}$ & $\begin{array}{r}-23.7 \\
-9.1 \\
4.0\end{array}$ & $\begin{array}{r}-6.5 \\
6.2 \\
18.0\end{array}$ & $\begin{array}{r}3.5 \\
14.7 \\
25.8\end{array}$ & $\begin{array}{r}8.6 \\
20.2 \\
32.0\end{array}$ & $\begin{array}{l}14.8 \\
27.0 \\
39.4\end{array}$ & $\begin{array}{l}24.4 \\
39.0 \\
51.4\end{array}$ & 42.6 \\
\hline H1. & -58.1 & -11.6 & 14.5 & 27.4 & 35.5 & 41.1 & 50.5 & & \\
\hline
\end{tabular}

TABLE 10.-Critical solution temperatures of mixtures with gasoline no. 8

\begin{tabular}{|c|c|c|c|c|c|c|c|c|c|}
\hline \multirow{2}{*}{ Alcohol solution } & \multicolumn{9}{|c|}{ Volume percent gasoline in mixture- } \\
\hline & 10 & 20 & 30 & 40 & 50 & 60 & 70 & 80 & 90 \\
\hline & ${ }^{\circ} \mathrm{C}$. & ${ }^{\circ} \mathrm{C}$. & ${ }^{\circ} \mathrm{C}$. & ${ }^{\circ} \mathrm{C}$. & ${ }^{\circ} \mathrm{C}$. & ${ }^{\circ} \mathrm{C}$. & ${ }^{\circ} \mathrm{C}$. & $\begin{array}{l}{ }^{\circ} \mathrm{C} . \\
-51.7\end{array}$ & ${ }_{-45.6}^{\circ} \mathrm{C}$ \\
\hline $\begin{array}{l}\text { A11... } \\
\text { B1-... } \\
\text { D1... }\end{array}$ & & -56.8 & $\begin{array}{l}-48.8 \\
-28.2\end{array}$ & $\begin{array}{l}-50.9 \\
-30.0 \\
-12.0\end{array}$ & $\begin{array}{r}-40.9 \\
-18.5 \\
-1.5\end{array}$ & $\begin{array}{r}-34.9 \\
-13.3 \\
2.1\end{array}$ & $\begin{array}{r}-28.2 \\
-9.2 \\
8.2\end{array}$ & $\begin{array}{r}-22.7 \\
-.8 \\
15.9\end{array}$ & $\begin{array}{r}-13.9 \\
9.8 \\
27.4\end{array}$ \\
\hline $\begin{array}{l}\text { E1...- } \\
\text { F1...- }\end{array}$ &..- & $\begin{array}{r}1-42.3 \\
-27.2\end{array}$ & $\begin{array}{r}1-14.1 \\
-.7\end{array}$ & $\begin{array}{r}1.9 \\
14.1\end{array}$ & $\begin{array}{l}11.2 \\
21.8\end{array}$ & $\begin{array}{l}15.5 \\
26.6\end{array}$ & $\begin{array}{r}21.9 \\
33.3\end{array}$ & $\begin{array}{l}31.5 \\
44.3\end{array}$ & 45.9 \\
\hline Q1.-........ & $\cdots$ & -13.6 & 13.3 & 25.4 & 33.1 & 37.6 & 45.8 & & \\
\hline & -49.8 & & & & & & & & \\
\hline
\end{tabular}

1 Solution E2.

\section{DISCUSSION OF EXPERIMENTAL DATA AND CONCLUSIONS}

The experimental data herein presented lead to three general conclusions:

1. With any given percentage of gasoline in the mixture between 10 and 90 percent, the critical solution temperature rises as the percentage of water in the ethyl alcohol increases.

2. With any given ethyl alcohol solution, containing from 1 to 8 percent of water, the critical solution temperature rises as the percentage of gasoline in the mixture is increased.

3 . With any given percentage of gasoline in the mixture between 10 and 90 percent, and with any given ethyl alcohol solution containing from 1 to 8 percent of water, the critical solution temperatures differ considerably with various gasolines.

The differences in the critical solution temperatures with various gasolines are due to differences in composition. Such differences may be associated partly with differences in volatility and partly with differences in the crude from which the gasoline was refined and the type of refining process used. Consideration of the data for the straightrun gasolines nos. 2 and 3, which have about the same volatility, shows that the critical solution temperatures for these two gasolines do not differ much, even though they are refined from different crude oils. A similar conclusion is reached on comparing the data for gasolines 
nos. 5 and 6 , which also have about the same volatility. While these conclusions are suggestive as regards the relative effects of volatility and source of crude oil, the data do not permit the quantitative evaluation of these two effects independently. In a later paper more definite information will be presented regarding the effect of variations in volatility on the critical solution temperatures.

The present data indicate definitely that separation would occur at any temperature below $0^{\circ} \mathrm{C}$. with any of the gasolines investigated when mixed with less than 50 percent of ethyl alcohol, unless the alcohol contains less than 3 to 5 percent of water. Even this concentration of alcohol leaves no margin of safety for absorption of moisture from the air after mixing and while in the supply tank of the automotive vehicle. A margin of safety is particularly desirable since separation into two liquid layers occurs at a temperature immediately below that at which turbidity is noted. With provision for a margin of safety to compensate for absorption of moisture, the alcohol used would have to be almost entirely free from water in order to prevent separation even at $0^{\circ} \mathrm{C}$. Since it is believed that the gasolines investigated cover the range of gasolines commercially available, it is considered that addition of other substances to increase the solubility of the alcohol is necessary if gasoline-alcohol mixtures that will not separate in service are to be obtained, unless alcohol almost entirely free from water is employed. (Information on the effectiveness of added substances in increasing the solubility of alcohol in gasoline, and on the required margin of safety against absorption of moisture from the air in service, is necessary before any safe estimate can be made of the highest permissible water content of the alcohol.

Washington, March 23, 1933. 